\title{
The influence of ethical dilemmas in the accounting
}

\author{
A influência dos dilemas éticos na contabilidade
}

\author{
Hugo Palácios \\ University of Algarve, Faculty of Economics, Campus de Gambelas, 8005-139 Faro, Portugal \\ hugopalaciosdasilva@hotmail.com \\ Joaquim Sant'ana Fernandes \\ University of Algarve, ESGHT, Campus da Penha, 8005-139 Faro, Portugal, \\ CIEO - Research Centre for Spatial and Organizational Dynamics, jsfer@ualg.pt \\ Cristina Gonçalves \\ University of Algarve, ESGHT, Campus da Penha, 8005-139 Faro, Portugal, \\ CIEO - Research Centre for Spatial and Organizational Dynamics, cjesus@ualg.pt
}

Gabriela Gonçalves

University of Algarve, Faculty of Human and Social Sciences, Campus de Gambelas, 8005-139 Faro, Portugal CIEO - Research Centre for Spatial and Organizational Dynamics, ggoncalves@ualg.pt

Cátia Sousa

University of Algarve, Faculty of Human and Social Sciences, Campus de Gambelas, 8005-139 Faro, Portugal CIEO - Research Centre for Spatial and Organizational Dynamics, cavsousa@ualg.pt

\begin{abstract}
In this study a theoretical model of five dimensions is explained - Rest (1986) ethical decision making process; Jones (1991) moral intensity; need for cognition; personal attributes and financial information - in order to understand the conditions that lead policymakers to manipulate information and to understand the ethical issues in decision-making that lead or not, to a more useful accounting. The sample, by convenience, consisting of 442 individuals and this empirical study was conducted through a survey by an online questionnaire. Data collection was performed using SurveyMonkey software and the model analysed by Structural Equation Analysis method. A structural model was obtained, seeming to indicate that the process of ethical and moral intensity decisions is associated with the individual need for cognition. The utility of accounting, preparation and presentation of financial statements are positively related to the educational level. In this sense, the results and the profitability of capital influence the moral intensity, it seems possible to conclude about the positive influence of academic ethics intention and accounting utility.
\end{abstract}

Keywords: Ethics, utility, accounting, behavioural, need for cognition.

\section{Resumo}

Neste estudo é explicado um modelo teórico de cinco dimensões - Rest (1986) processo de tomada de decisão ética; Jones (1991) intensidade moral; necessidade de cognição; atributos pessoais e informações financeiras - com o objetivo de compreender as condições que levam os legisladores a manipular informações e a compreender as questões éticas na tomada de decisões que conduzem ou não a uma contabilidade mais útil. A amostra, por conveniência, composta por 442 indivíduos e o presente estudo empírico foram realizados através de um questionário online. A recolha de dados foi efetuada utilizando o software SurveyMonkey e o modelo foi analisado pelo método de Análise de Equações Estruturais. Foi obtido um modelo estrutural, que parece indicar que o processo de decisão ética e de intensidade moral está associado à necessidade individual de cognição. A utilidade da contabilidade, preparação e apresentação das demonstrações financeiras estão positivamente relacionadas com o nível educacional. Nesse sentido, os resultados e a rentabilidade do capital influenciam a intensidade moral, parecendo possível concluir sobre a influência positiva da intenção ética académica e da utilidade da contabilidade.

Palavras-chave: Ética, utilidade, contabilidade, comportamento, necessidade de cognição.

\section{Introduction}

The output generated by accounting will be useful for decision making to a wide range of users, if the financial statements of an entity translate a true and fair view of the transactions and other events in a particular economic period (Ministério das Finanças, 2015). Since the twentieth century, the financial information is prepared based on the utility paradigm that focuses primarily on the purpose of the financial statements and their recipients (Coy, Fischer, \& Gordon, 2001).

Economic paradigms and their relationship to information lead us to the concept of accounting information system. This organizes and produces information in order to assess the performance of a company. According to the information theory, accounting is defined as an information system that aims to identify, measure and report all relevant information for decision making of the economic/financial reality of an entity, in a given time, to all interested users. It must produce and disseminate reliable and relevant financial information to its users, since the decision making process can be affected by the quality of information (Almeida \& Silva, 2013).

The existence of ethics, as the underlying assumption of accounting information systems, it is essential to ensure the proper functioning of the systems needed for their processing, storage, availability and dissemination. Thus, it allows increase the value and usefulness of the information, reducing the chances of 
misrepresentation or inaccuracies of the outputs, as a result of the amendment procedures of deliberate tampering of data or the alteration of the treatment standards (Rascão, 2012). Caňibano and Angulo (1997) fall under the accounting information within a decision-making model, as a kind of raw material, which is influenced by the context and the decision maker's characteristics, whose efficiency is measured by its usefulness.

The need for credibility in financial reporting, justifies, on the one hand, this study, since it is essential to understand the influence of the human factor on financial information systems and how human characteristics, individual decisions, judgments and motivations have an impact on the information production and dissemination.

For Rest, Bebeau and Volker (1986), making ethical decisions corresponds to a process that involves the identification of an ethics problem, the recognition of various courses of action and the choice of the one that maximizes the ethical values, allowing achieve the intended purpose. This ethical decision making is particularly complex when the decision maker has to face an ethical dilemma. According to Blackburn (1997: 114) there is an ethical dilemma in a situation: "(...) where each possible course of operating violates a certain moral principle which is also, in turn, required (...)". In this context, the credibility of accounting information is dependent on the choices made by the decision maker.

It was defined, as the main objective of this study, to explore an ethical behaviour model, considering the interrelationships between the following dimensions: process of ethical decision making (Rest, 1986); moral intensity (Jones, 1991) and need for cognition and personal attributes, which together can influence both the inputs (data processing) and the outputs, generated by accounting. Based on a quantitative study and using the Structural Equation Modeling (SEM), it is the authors' expectation that the results point to a model in which the various dimensions are interrelated and reveal an association with the necessity of the individual cognition. The individual's predisposition to a more informed decision places it in order to have a better ethical judgment and consequently a greater ethical intention. It is also the authors' expectation that the educational level affect positively the need for cognition.

\section{Literature review}

The leaders of the companies' decisions have a significant and widespread influence in various business branches. This influence has an impact on the credibility and confidence that companies convey to investors, lenders, employees and all other stakeholders that relate to the company.

In the context of classical economics, the traditional decisionmaking is based on the classical model of unlimited rationality of economic agents. According to this model, the human being in its decision-making process, has total capacity to process all existing assumptions and available information, and subsequently, analyse and rank all relevant information and available alternatives to solve the problem, by always choosing the optimal solution or the preferred alternative (e.g., Feitosa, 2010; Silva, 2009). In turn, Simon $(1959,2013)$ argues that there are limits on the ability of humans to process information. In order to make decision models most realistic, the author introduced, in his model, limits to rationality in decision making.
In this perspective, the individual opts for a satisfactory or reasonable choice, sacrificing the optimal solution, and choose the alternative that gives he/she his/her acceptable level of performance (Lobão, 2015).

Studies that analyse behavioral decision question the rationality of economic agents, concluding that the managers' decisions are also taken according to their cognitive characteristics and show behavioral and/or emotional biases on decision-making (Barbosa, 2013; Melo \& Silva, 2010).

Tversky and Kahneman (1981) recognize that decisions are not always made in accordance with the rational model of decision making and, not rarely, are adopted intuitive and emotional processes. This cognitive side, which is based on heuristic rules and simplifying strategies (Bazerman \& Moore, 2012), creates biases that result in the reduction of the decision quality (Silva, 2009).

In dual processing models, some authors argue that the domain (rationality versus intuition) varies according to the specific situation (Sonenshein, 2007), however, in low uncertainty conditions the rational mode prevails. Though, for Woiceshyn (2011) intuitive and subconsciously mode prevails in complex situations and under time pressure, for example, in ethical dilemma contexts. Based on a study about the managers' strategic decisions, Woiceshyn (2009) noted that they used a dual decisionmaking process that involves thinking (conscious processing) and intuition (subconscious processing).

The heuristic model - systematic, with a sociocognitive base (Chaiken, 1980), proposes a relationship between motivation for cognition and judgment, demonstrating how individuals adopt a heuristic cognitive processing when they are not motivated to think about the content of the information and, on the contrary, a systematic processing when they are highly motivated and available for its analysis (Chen \& Chaiken, 1999, cit. in Miranda 2013).

In this dual perspective, the individual involvements with the most rational, detailed and elaborate information processing or the most intuitive processing, is not a choice, nor has optional nature. There is not any kind of hierarchy or sequential pattern between the two types of processing. The way human reasoning switches between the two, depends on the interaction of several less predictable factors such as the context and the decision maker's personality.

One of these factors is the need for cognition defined by Cacioppo and Petty (1982) as the tendency of individuals to get involved and obtain pleasure in cognitive activities which results from the commitment to cognitive effort; preference for complexity and desire for understanding. As a personality trait (e.g., Furnham \& Thorne, 2013; Sadowski \& Cogburn, 1997), it influences directly the type of information processing to be used, since all individuals have cognitive limitations and levels of motivation to cognition. In summary, it can be said that individuals with high need of cognition tend to use a more rational process, while those with low levels prefer to avoid cognitive activities.

Filho et al. (2013) developed a study in order to validate the scale of cognitive needs in the Brazilian context and in Behavioral Accounting studies and thus measure the correlations between the level of need for cognition and the existence of cognitive biases in financial and accounting decisions. In this study it was observed 
the impact of cognition level on maximizing the occurrence of heuristics in management decisions and that the cognition need's level is associated with the presence of heuristics. According to the same authors "... in every score increase [cognition needs], the probability of presenting high heuristic is 0,98 times higher than to present lower cognitive bias, i.e., the chance to present heuristics is almost double in individuals with low need for cognition that in individuals with high need for cognition..." (pp.130).

This results are consistent with Silva's (2009) results, who used as an independent variable the cognitive needs, and noted that depending on the need for cognition (high vs. low) people tend to get involved in a conscious, systematic and complex way to solving the problem or prevent cognitive effort relying on cognitive heuristics and consequently making more mistakes of judgment.

The presence of psychological, automatic and unconscious mechanisms, raises the question of how individual, motivational (need for cognition) and contextual (moral strength) factors, can affect the relationship between the process of individual decisionmaking and ethical behavior, with consequent effects on the financial information.

The ethics approach in decision-making is justified to the extent that its purpose is to define the acceptable behavior. Taking into account that institutions are composed by people this necessarily implies that business decisions depend on intrinsically human factors, thus, beyond the personality and cultural aspects, among others, we must also consider the ethical values (Lobão, 2013).

In this context Pohling, Bzdok, Eigenstetter, Stumpf and Strobel (2015) conceptualize ethical competence as the awareness of the responsibility of taking a decision before a particular situation. The individuals should feel obliged to act in accordance with legal standards, in a socially responsible manner and according to their own ethical principles.

Unethical decisions can undermine the decision maker, the company itself, and all those that directly or indirectly relate to it. Thus, it is not at all irrelevant, whether people make ethical or immoral decisions, once the consequence of these decisions can make a significant difference in each other's life. The better to understand how they make these decisions, the better prepared we are to take their results.

Inspired by Kolhberg (1976) on the cognitive basis of the moral judgment field, the Rest's (1986) model contains four sequential, conceptually distinct, stages of the ethical dimension, which must be followed by an individual to make a decision that is considered as an ethically correct behavior: identification of an ethical dilemma, ethical judgment, ethical intention and ethical behavior.

Thus, we formulate the first three hypotheses in order to analyse the existence of significant positive correlations between the first three stages of the Rest's model (1986). The last step of the process, ethical behavior, is represented as a latent variable, defined from the set of the first three, since it can not be directly observed:

$\mathrm{H} 1$ : The identification of an ethical dilemma is positively related to the ethical judgment and $(\mathrm{H} 2)$ ethical intention.

H3: The ethical judgment is positively correlated with ethical intention.
The Rest's model (1986) does not consider the influence of situational, motivational and cognitive factors, framing the ethical decision at the individual level. The Jones's model (1991) rectifies this deficiency and contemplates the relationship between individual and contextual factors in ethical decision making (Miranda, 2013).

In this sense, he develops a multidimensional model of moral intensity consisting of six components, which can influence any of the stages of of the Rest's ethical decision making model (1996):

- Magnitude of Consequences, total benefits or losses caused by the individual moral action upon the respective beneficiaries or victims;

- Proximity, the feeling of closeness (social, cultural, physical or psychological);

- Social Consensus, the degree of social agreement that moral action is beneficial or harmful;

- Probability of Effect, the probability of when moral action will occur and the expected effects;

- Temporal Immediacy, the time interval between moral behavior and its consequences (the lower the range the greater immediacy);

- Concentration of Effect, the number of people affected by the moral behavior because of a certain magnitude

Several studies (e.g., Carlson, Kacmar, \& Wadsworth, 2009; Leitsch, 2004) resorted to Rest (1986) and Jones's (1991) models to test the impact of different factors in the decision process. Sweeney and Costello (2009) tested the relationship between the six components of Jones's model (1991) and the three stages of the ethical dimension (Rest's model, 1986) and concluded that the moral intensity is related to the identification of an ethical dilemma. Pereira (2014) validated the survey used by Sweeney and Costello (2009) for the Portuguese population and its conclusions were identical.

Miranda (2013) used as a covariate the moral intensity scale of Jones (1991), studied the social cognitive processing, as an antecedent of ethical behavior, and analysed the effect of need for cognition as a factor whose presence varies the relationship between the systematic cognitive processing and the ethics of decision. According to the author the need for cognition influences the relationship between the systematic cognitive processing and the ethics of decision. On the other hand, it seems to guide individuals to choose a more methodical cognitive processing, using more detailed information and giving more importance to the sociological processes acquired throughout life.

Several authors concluded that social consensus (Barnett, 2001), the magnitude of consequences (Marshall \& Dewe, 1997) and the probability of effect (Singhapakdi, Vitell, \& Kraft, 1996) are positively related to the identification of an ethical dilemma. On the other hand, May and Pauli (2002) did not find any relationship between the social consensus and the identification of an ethical dilemma, and Leitsch (2004) noted that the components of moral intensity are not significantly related to the moral sensitivity, being this, the ability to recognize and identify ethical issues.

Taking this into consideration, the following hypothesis is formulated: 
$\mathrm{H} 4$ : Moral intensity is positively related to the identification of an ethical dilemma.

Other authors (e.g., Karacaer, Gohar, Aygün, \& Sayin, 2009; Sweeney \& Costello, 2009; Pereira, 2014) identified significant correlations and influences of the various components of moral intensity and ethical judgment. Despite Barnett and Valentine (2004) corroborate the results of Singhapakdi et al. (1996) with regard to the relations of magnitude, of the consensus and the likelihood with ethical judgment, they found no relationship with temporal immediacy.

Of the different components of moral intensity, and towards the relations with the stages of ethical decision making, in Carlson et al. (2009) work, the proximity had a significant impact on the judgment of a situation, reflecting the idea that the closer the individual is to the situation the greater is her/his perception of ethics. In contrast, Barnett and Valentine (2004) and McMahon and Harvey (2007) concluded that proximity does not have a significant effect on the ethical judgment and the Sweeney and Costello's (2009) work, presents a very low relationship. Hence considering the following hypothesis:

$\mathrm{H} 5$ : Moral intensity is positively related to ethical judgment.

The components of moral intensity were significant predictors of moral intentions. Leitsch, (2004) e Karacaer et al. (2009) corroborated these findings in which the perception of intensity influences intentions. Pereira (2014) concluded that moral intensity is related to intention.

Shafer and Simmons (2011) concluded that in low moral intensity settings, the consequences have a significant effect on behavioral intentions, but the impact on ethical behavior was weak.

Different authors found relationships between ethics intention and social consensus (Jones \& Huber, 1992) and the magnitude of the consequences (Cohen, Pant, \& Sharp, 2001; Flannery \& May, 2000). However, Singhapakdi et al. (1996) do not consider that the proximity has influence on intention. Considering this, the following hypothesis is formulated:

H6: Moral intensity is positively related to ethical intentions.

Regarding the type of situation (scenario), several authors have identified its influence on moral intensity (Leitsch, 2004; Sweeney \& Costello, 2009) and on ethical intentions (e.g., Robin, Reidenbach, \& Forrest, 1996).

Leitsch (2004) noted that the three phases of Rest (1986) as well as the Jones's (1991) components of moral intensity varied according to different situations. In turn, Pereira (2014) noted that the accounting issues influenced the moral intentions and the elements of moral intensity, reflecting significant differences between each scenario. Thus the following hypotheses are defined:

H6a: Different situations/scenarios influence the components of moral intensity.
H6b: Different situations/scenarios influence the steps of ethical dimension.

According to Tversky and Kahneman (1981) when individuals make decisions they do not resort exclusively to the rational model, but they use more intuitive and emotional processes.

Barbosa (2013) concluded that some of the managers' decisions are influenced by their cognitive characteristics. Individuals who have more motivation for cognition consider ethical aspects more significantly or take more ethical decisions than individuals focused on obtaining results (Miranda, 2013).

Lower or higher levels of need for cognition appear to predispose people to the use of the Chaiken's (1980) heuristic-systematic model that relates the type of processing with the motivation to analyse in detail the information available to decision-making. According to Trevino (1986) ethical judgment is strongly influenced by moral and cognitive development.

The more systematic is the decision-making process, more careful, thorough and detailed is the analysis of information, as well as the influence of moral principles, laws and regulations (Miranda, 2013). There is greater availability for advice with other individuals, to consider the others' opinions or the consequences of the decision (Curseu, 2011). In this sense:

H7: The level of need for cognition has an effect on individuals' ethical decision making and moral intensity behaviors.

Moreover, since less cognitive biases are used in the decisionmaking, improving the usefulness of Accounting, it is expected that the educational levels enlarge that predisposition and reduce the risk of information, by increasing the relevance and reliability of the financial information. Considering this, the following hypothesis is formulated:

H8: The educational level has a positive effect in need for cognition.

\section{Empirical study}

\subsection{Model}

It was defined as the objective of this study to explore an ethical behavior model considering the interrelations dimensions of the ethical decision-making process (Rest, 1986); moral intensity (Jones, 1991); need for cognition and personal attributes, through SEM analysis.

We began by building a theoretical model (figure 1) which is based on an accounting information system, where inputs and outputs (financial data) are dependent on the interrelations of these four dimensions. Ethical decision-making is considered as an element that can increase the credibility of financial information by reducing the risk of financial information. So, it represents the set of hypotheses able to test and explain the influence of ethics in utility accounting. 
Figure 1. Theoretical Model

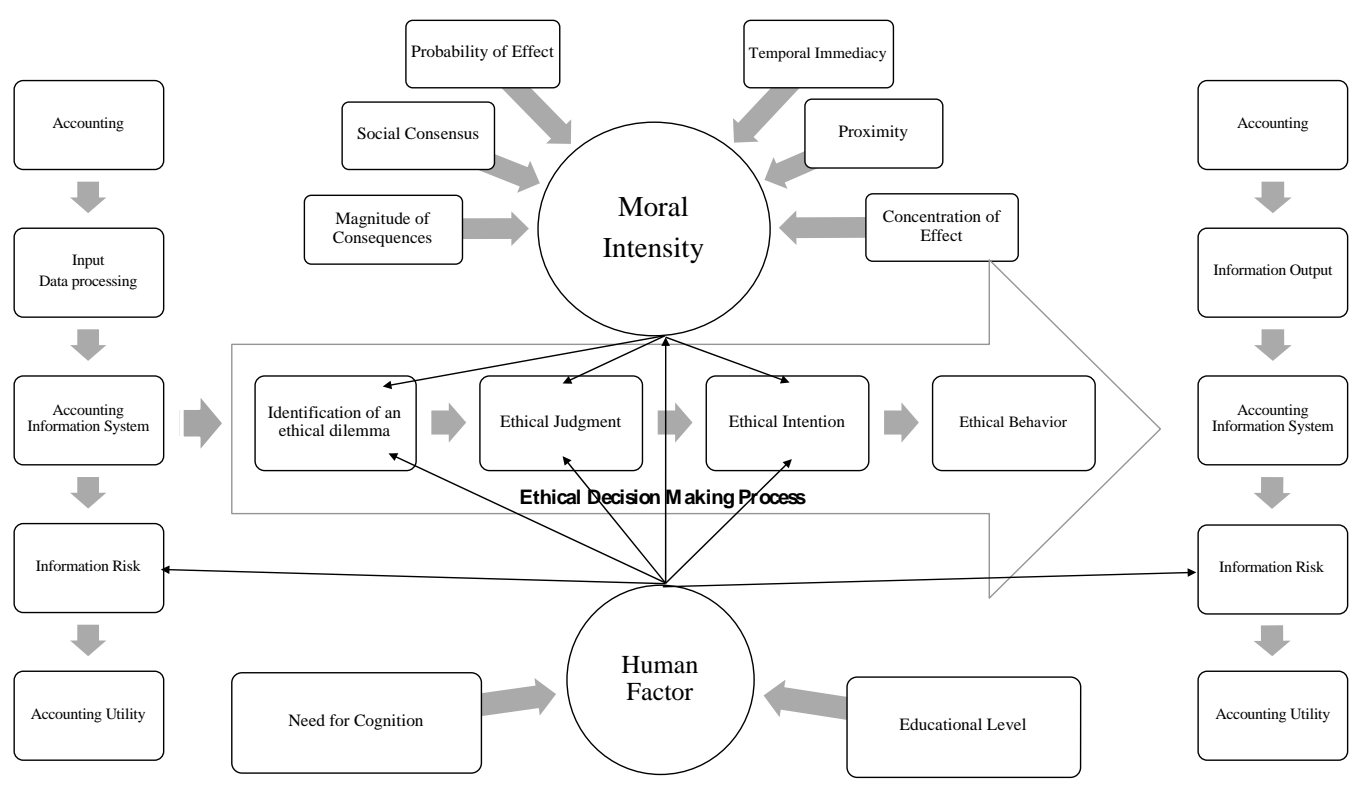

Source: Authors.

\subsection{Universe and sample}

The National Statistics Institute (INE, 2014), refers to the existence in 2012 of 352,596 micro, small and medium enterprises (MSME), representing $99,7 \%$ of the non-financial sector (NFS). Micro enterprises predominated, constituting about $88,3 \%$ of total of MSME- The economic activity sector, the so-called "other services" concentrated the largest number of companies with 139,034 (39,3\%).

The universe of this study consists of the members of the executive body of the 139,034 companies whose economic activity (classification of economic activity - CAE), is included in the sections of $M$ to $S$ (INE, 2014), except for section O, the Portuguese classification of economic activities - Revision 3 (other services). The option by CAE is justified by its quantitative weight in the Portuguese business, since they represent the set of activities with the largest number of companies.

This sample was obtained through SABI database, where the elements were chosen because they were available and meet the defined criteria. Thus, the sample is no probabilistic for convenience.

We obtained a total of 2026 replies, of these 442 were validated and 292 are men $(66,06 \%)$. All individuals are aged over 24 years, and $169(38,23 \%)$ are aged between 40 and 49, and mostly of Portuguese nationality (97,06\%). About 193 (43,67\%) are residents in the metropolitan area of Lisbon and $75(16,97 \%)$ in the metropolitan area of Porto. Beiras, Estremadura and Ribatejo account for $68(15,38 \%)$ and the rest reside in the Algarve. As for educational level, 370 participants $(83,71 \%)$ has a university degree or higher. About 206 participants $(46,61 \%)$ have a degree, being economics, management and accounting the most represented areas of study (178, representing $40,27 \%)$.

\subsection{Instrument and materials}

It was used a questionnaire as a tool to test the hypotheses developed, using the online survey software SurveyMonkey ${ }^{\circledR}$.
The questionnaire format took account of the complexity of the issues and the required response time, presenting first the items whose response required more intellectual concentration, in an inverse relationship with fatigue and motivation (Moreira, 2009), which after its presentation note, shows the following structure:

Identification data: Function, department, number of employees, total balance and CAE.

Need for Cognition Scale (reduced version, Cacciopo, Petty, \& Kao, 1984): adapted version for the Portuguese population by Gomes et al. (2013) Includes 18 ordinals items assessed on a Likert scale from 1 (Strongly Disagree) to 7 (Totally Agree). This scale had a structure of three factors (cognitive effort, preference for complexity and desire for understanding) and good consistency values replicating the original model and the results of Gomes et al. (2013).

Scenarios (A, B, C and D), with simulation of ethical dilemmas in professional environment, related to the qualitative characteristics of financial information. With this relationship it was ensured the influence of the decision maker's action in the utility accounting, as well as the positioning of the participants, both in ethical decision making and moral intensity. Each scenario includes 9 issues, assessed on 7 points Likert scale (1-Strongly Disagree, 7- Totally Agree). The item concerning the temporal immediacy is quoted in reverse.

The 9 items $\times 4$ scenarios measure the ethical dimension of the members of the management body, through the observable variables: identification of an ethical dilemma, ethical judgment, ethical intention, magnitude of consequences, proximity, social consensus, probability of effect, temporal immediacy and concentration of effect. Scenario A was adapted from Babb (2013) the others, inspired by the work of Torre and Proença (2010). To measure the ethical decision making, 3 items were used and to measure the moral intensity, 6 items were used (Sweeney \& Costello, 2009, translated and validated by Pereira, 2014). The 
questions correspond to the six observable variables, elements of the moral intensity of Jones (1991).

Only the group "scenarios" was not validated. Thus, for this purpose, the four scenarios and only the first item for each scenario, was sent to a group of judges. "The scenario described involves an ethical dilemma" with a Likert scale of 7 points, where 1 means strongly disagree and 7 means totally agree.

The panel of judges was divided into two subgroups called Accountants (composed of six experts in ethics, management and accounting) and Psychologists (composed of six experts in psychology of ethical dilemmas and behaviors). These assessed the extent to which each scenario is an ethical dilemma. The four scenarios obtained means between 4,5 and 5 . The internal consistency was adequate (Cronbach's alpha $=0,880$ ).

Depending on the level of agreement of these judges, the scenarios were considered validated. The factor analysis showed the expected dimensionality, as well as good indicators of items homogeneity and internal consistency (between 0,620 and 0,802, Maroco, 2003).

Posteriorly the questionnaire was previously tested in order to validate its feasibility (Gil, 2002), through its completion by 20 preselected individuals and similar to the group in study. The participants were asked to comment ambiguities and criticise the wording and the use of technical terms (Marconi \& Lakatos, 2003). Identified the problems, the necessary changes were made and as well as a second pre-test which did not present any problems. This study data was collected between April 12 and June 1, 2015.

\section{Results and discussion}

The data analysis was performed using the SPSS 22 statistical package and AMOS 20 software. Based on the responses obtained, descriptive statistics of mean and standard deviation of the nine items presented in each scenario, and correlation analysis were calculated. The descriptive analysis for all scenarios showed that the means of identification of an ethical dilemma are in line with the mean of ethical intention. A convergence of results was also noted, with respect to components with higher and lower moral intensity. It was found that there were significant correlations between the stages of the decision-making process and between the identification of an ethical dilemma and the ethical judgment in all scenarios (serves as a support to $\mathrm{H} 1$ ), as well as between ethical judgment and ethical intention, thus supporting $\mathrm{H} 3$. With respect to $\mathrm{H} 2$, it is supported by the significant negative correlation found in scenarios 3 and 4 . It is noted the inverse relationship between "M_intention"/"Consequences" and "M_judgment"/"M_intention". Given that the ethics intention measures an undesirable behavior, it is clear that respondents who better perceive the dilemma, show less intention of an unethical behavior.

According to the purpose of the study and the recommendations of Maroco (2010) we used the SEM to assess the relationships between the different variables. We chose to perform the analysis using the data of the four scenarios simultaneously and make the processing of data in IBM AMOS ${ }^{\circledR}$ (v.22) software. The results are disclosed in figure 2 . The quality indices (Maroco, 2010) confirm a good fit of the model, with $X^{2}=72,885 ; \mathrm{p}=0,162 \mathrm{P}\left(X^{2}>0.05\right)$; $X^{2} / \mathrm{df}=1,176 ; \mathrm{CFI}=0.991 ; \mathrm{GFI}=0.976 ; \mathrm{RMSEA}=0.02 ; \mathrm{P}(\mathrm{rmsea} \leq 0.05)$.

Figure 2 - SEM Structural Model

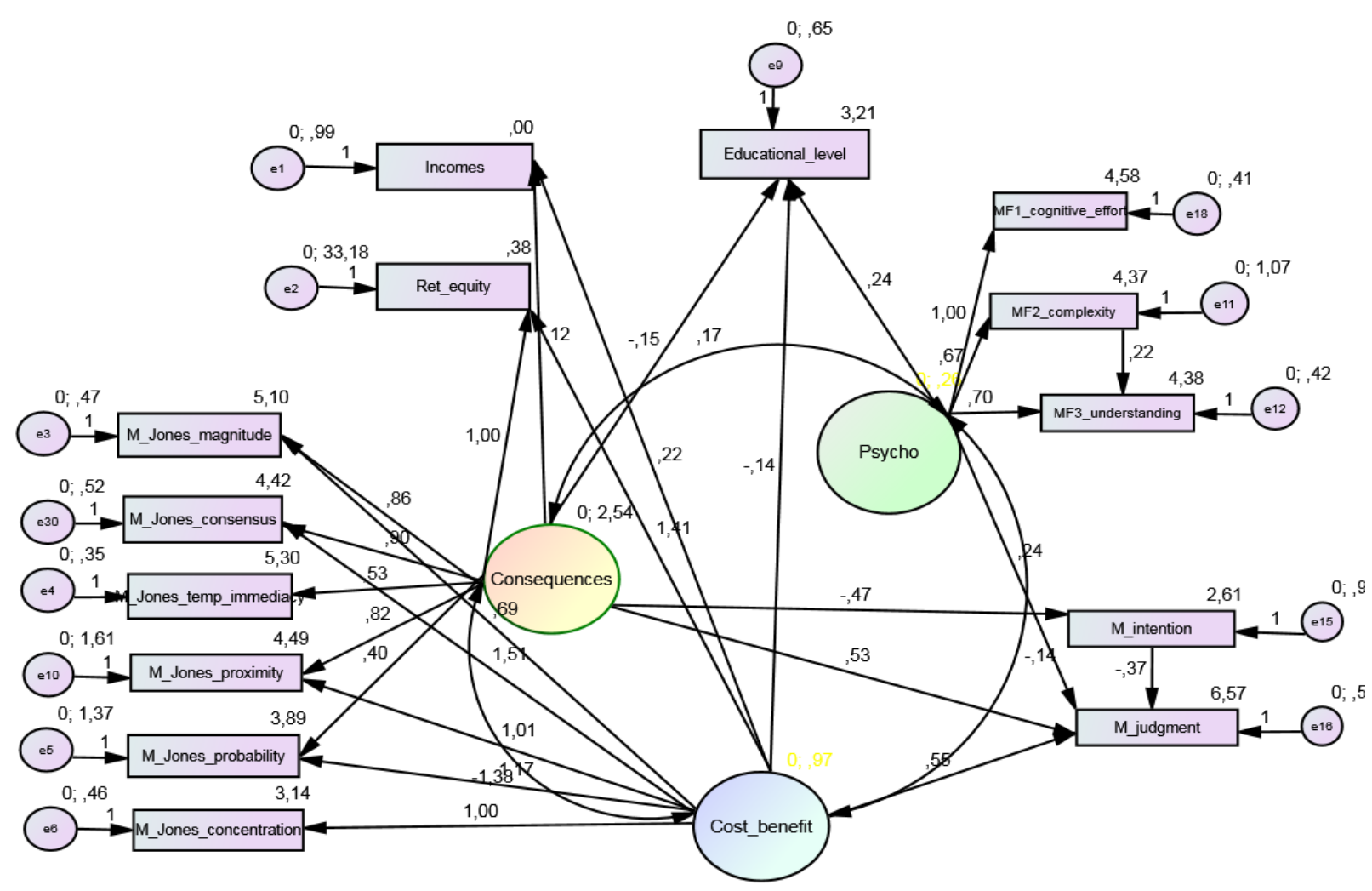

Source: Authors. 
From the SEM resulted a model with three latent variables ("consequences", "cost-benefit", "psycho" obtained by factor analysis) correlated and explained by observed variables. The data point to a relationship of influence between ethics (ethical decision making and moral intensity) and the human factor (need for cognition and educational level). All results of the absolute regression coefficients are significant $(p \leq 0,001)$, except for the effect of "consequences" in the " educational level ".

The model does not manifest any relation to the identification of an ethical dilemma ( $\mathrm{H} 1, \mathrm{H} 2, \mathrm{H} 4)$ and as Leitsch (2004), the moral sensitivity (ability to recognize and identify ethical situations) was not significantly related to the other variables in the model. However, there was a significant negative correlation $(B=-0,424$ $p<0,001)$, between ethical judgment and ethical intention (H3) $(p<0,001)$. This negative correlation is justified since ethical intention mediates a non-desirable behavior and supports the idea that the greater the ethical judgment the lower the intention to make an unethical decision. It is observed a relationship between the variables of moral intensity and the factor "cost-benefit" ( $p<$ 0.001), according to the study of Sweeney and Costello (2009).

As Fig.2, the ethical judgment explains part of latent variables "consequences" and "cost-benefit " (H5) replicating other studies (e.g., Karacaer et al., 2009).

The effect of "intention" in the "judgment" as well as the effect of "cost-benefit" in the "judgment" ( $p<0.001)$, confirm other studies (e.g., Karacaer et al., 2009; Leitsch, 2004) where moral intensity components are significant predictors of moral judgment. Indirectly, through the factor "cost-benefit", proximity seems to have an impact on the judgment leading to a higher ethics perception ( $p<0,001)$, such as Carlson et al. (2009). Regarding the relationship between ethics intention and "consequences", the data confirm the $\mathrm{H} 6$ replicating the results of the study of Karacaer et al. (2009). Once the items measured in the 4 scenarios were the same, we worked with the mean response obtained in order to simplify the calculations and relationships between variables, however, the negative sense of the relationship of ethics intention to the ethical judgment (stage of the ethical dimension - H3) and to the factor "consequences" (components of the moral intensity - H6), they seem to indicate that the type of action, different situations or scenarios, influence relations $(\mathrm{H} 7)$. In short, the dichotomy between ethical judgment and the "consequences" seem to influence the action taken by the individual, in accordance with Sweeney and Costello (2009) and Leitsch (2004) regarding the moral intensity and Robin et al. (1996) on ethical intentions. The latent variable "psycho" is supported by the three-factor structure of need for cognition scale (Gomes et al., 2013) and the observed variables, "judgment" and "educational level". The need for cognition of the individual is correlated with the variables "consequences" and "cost-benefit". This correlation is consistent with Tversky and Kahneman (1981) and others in which individuals when making decisions do not resort exclusively to the model. Although there is covariance between the latent variables "psycho", "consequences" and "cost-benefit" (H7), only the covariance between the "cost-benefit" and "psycho" is significant (cov=-0,284, $p<0,001$ ).

Although it can not be concluded as Trevino (1986), that ethical judgment is strongly influenced by moral and cognitive development $(b=0,113, p<0,05)$, it is sufficient to support the work of Barbosa (2013) in which management decisions are influenced by their cognitive characteristics. The level of need for cognition has effect on ethical decision making of individuals, through ethical judgment $(H 7)(p<0,05)$. Fleischauer et al. (2010) concluded that there is a significant relationship between the need for cognition and the presence of heuristics and confirmed that they are inversely proportional magnitudes. Thus, it seems that the moral intensity is influenced by educational level through the greater or lesser presence of heuristics and hence correlated with the necessity of cognition ( $\mathrm{H7} 7$ ). Although there is negative relationship with the factors "consequences" $(\beta=-0,162)$ and "cost-benefit" $(\beta=-0,282)$, the cases identified as not significant concern the relationship between these variables.

There is an effect of educational level on the "psycho" variable (H8), which manifests itself in a positive relationship $(\beta=0,148$, $p<0,05)$ replicating the results of Gomes et al. (2013) in which individuals with more need for cognition have more education, ensure access to more skilled professions and analyse information in a more detailed and based on normative aspects and legal principles (Miranda, 2013).

\section{Conclusions}

The human ability to make rational decisions is commonly seen as one of the most important processes at the mental level. This decision making involves the estimation of a set of probabilities whose selection determines the individual's action. However, despite the cognitive tools that man has to process information, before deciding, he often appeals to heuristics (Kahneman \& Tversky, 1979) leading to cognitive biases.

The process of ethical decision-making was assumed as the ability of an individual to asses ethically, the right and the wrong. In the case of a decision process with specific characteristics, with direct influences, both in moral intensity and in human characteristics, it is noticeable the relationship to the need for cognition.

Being Accounting an information system, which should be useful for decision making, it is expected the inverse relationship between the qualitative characteristics (in particular the relevance and reliability), the risk of information and the need for cognition.

The results fit to the proposed model, in which the dimensions (process of ethical decision making of Rest (1986), moral intensity of Jones (1991), need for cognition and personal attributes) directly or indirectly arise related and suggests that moral intensity shows a strong association with the necessity of individual cognition. The predisposition of the individual to a more informed decision and less prone heuristics places it at the level of moral intensity, in order to have a better ethical judgment and consequently a greater ethics intention. On the other hand, the educational level appears to increase less cognitive biases in decision making.

The non-random sampling limits the generalization of the results, however, in studies of social research, non-random methods are acceptable (Maroco, 2003).

The study of the influence of the human factor in the accounting information system is a very undeveloped research field in Portugal, so we suggest that future studies introduce in the model economic/financial variables, such as net income and return on equity. The introduction of cultural variables (comparative studies with other countries) will allow not only deepen this field of 
research but also better understand the influence of the human factor on accounting.

\section{Acknowledgements:}

This article is funded by National Funds through FCT - Foundation for Science and Technology under project UID / SOC / 04020/2013.

\section{References}

Almeida, B. \& Silva, A. (2013). Integração das teorias explicativas da auditoria no modelo de accountability de Laughlin: análise teórica e empírica. Contabilidade e Gestão, 14, 43-102.

Barbosa, A. S. (2013). Características do gestor e estrutura de capital nas empresas cotadas. Dissertação de mestrado não publicada, Universidade de Aveiro, Aveiro.

Barnett, T. (2001). Dimensions of moral intensity and ethical decision making: An empirical study. Journal of Applied Social Psychology, 31(5), 1038-1057.

Barnett, T., \& Valentine, S. (2004). Issue contingencies and marketers' recognition of ethical issues, ethical judgments and behavioral intentions. Journal of Business Research, 57(4), 338-346.

Bazerman, M. \& Moore, D. (2012). Judgment in managerial decision making (8th ed.), New York: John Wiley \& Sons, Inc.

Blackburn, S. (1997). Dicionário de Filosofia. Lisboa: Editora Gradiva.

Cacioppo, J. \& Petty, R. (1982). The need for cognition. Journal of Personality and Social Psychology, 42(1), 116-131.

Cacioppo, J., Petty, R. \& Kao, C. (1984). The efficient assessment of need for cognition. Journal of Personality Assessment, 48, 306-307.

Caňibano, L. C., \& Angulo, J. A. (1997). Los programas de investigación en contabilidad. Revista de Contabilidad, 0, 57-95.

Carlson, D., Kacmar, K., \& Wadsworth, L. (2009). The impact of moral intensity dimensions on ethical decision making: Assessing the relevance of orientation. Journal of Managerial Issues, 21(4), 534-551.

Chaiken, S. (1980). Heuristic versus systematic information processing and the use of source versus message cues in persuasion. Journal of Personality and Social Psychology, 39(5), 752-766.

Cohen, J., Pant, L. \& Sharp, D. (2001). An examination of differences in ethical decision-making between Canadian business students and accounting professionals. Journal of Business Ethics, 30(4), 319-336.

Coy, D., Fischer, M., \& Gordon, T. (2001). Public accountability: a new paradigm for college and university annual reports. Critical Perspectives on Accounting, 12(1), 1-31.

Culhane, S., Morera, O. \& Hosch, H. (2004). The factor structure of the Need for Cognition Short Form in a Hispanic sample. The Journal of Psychology, 138(1), 77-88.

Curseu, P. (2011). Need for cognition and active information search in small student groups. Learning and Individual Differences, 21(4), 415-418.

Deliza, R., Rosenthal, A. \& Costa, M. (2003). Tradução e Validação Para a Língua Portuguesa de questionário utilizado em estudos de consumidor. Ciência e Tecnologia de Alimentos, 23(1), 43-48.

Feitosa, A. B. (2010). Excesso de confiança, otimismo e ancoragem em gestores da construção civil no Brasil: Estudo de caso da Camargo Correa. Projeto de Mestrado, ISCTE Business School, Lisboa.

Filho, R., Bruni, A. \& Menezes, I. (2013). Validação do teste Need For Cognition: Um estudo em Contabilidade Comportamental. Psicologia, Ciência e Profissão, 33(71), 112-131.

Flannery, B. \& May, D. (2000). Environmental ethical decision making in the US metal finishing industry. The Academy of Management Journal, 43(4), 642-662.

Forsterlee, R., \& Ho, R. (1999). An examination of the short form of the Need for Cognition Scale applied in an Australian sample. Educational and Psychological Measurement, 59(3), 471-480.
Furnham, A., \& Thorne, J. D. (2013). Need for cognition: Its dimensionality and personality and intelligence correlates. Journal of Individual Differences, 34(4), 230-240.

Gil, A. (2002). Como elaborar projetos de pesquisa (4.a ed.). São Paulo: Editora Atlas.

Gomes, A., Santos, J., Gonçalves, G., Orgambidez-Ramos, A., \& Giger, J.-C. (2013). Estudo de validação da Escala de Necessidade de Cognição com amostra portuguesa. Avaliação Psicológica, 12(2), 179-192.

Instituto Nacional de Estatística (2014). Empresas em Portugal 2012 Destaque. Lisboa. Retrieved January 10, 2016 from www.ine.pt $/$ xportal $/ x$ main? $x p i d=I N E \& x p g i d=$

ine_publicacoes\&PUBLICACOESpub_boui $=210758098$ \&PUBLICACOESmod $\mathrm{o}=2$, (acedido em: 10.01.2015).

Jones, T. (1991). Ethical decision making by individuals in organizations: An issue-contigent model. The Academy of Management Review, 16(2), 366395.

Jones, T. \& Huber, V. (1992). Issue contingency in ethical decision making. International Association for Business and Society Proceedings, 156, 166.

Kahneman, D. \& Tversky, A. (1979). Prospect Theory: An Analysis of Decision under Risk. Econometrica, 47(2), 263-292.

Karacaer, S., Gohar, R., Aygün, M. \& Sayin, C. (2009). Effects of Personal Values on Auditor's Ethical Decisions: A Comparison of Pakistani and Turkish Professional Auditors. Journal of Business Ethics, 88(1), 53-64.

Kohlberg, L. (1976). Moral stages and moralization: The cognitivedevelopmental approach. Moral Development and Behavior: Theory, Research, and Social Issues, 31-53.

Leitsch, D. (2004). Differences in the Perceptions of Moral Intensity in the Moral Decision Process: An Empirical Examination of Accounting Students. Journal of Business Ethics, 53(3), 313-323.

Lisboa, L. (1997). Ética Geral e Profissional em Contabilidade. São Paulo: Editora Atlas.

Lobão, J. (2013). O Factor Humano na Decisão Empresarial. Coimbra: Actual Almedina.

Lobão, J. (2015). Finanças Comportamentais. Coimbra: Actual - Almedina.

Marconi, M. \& Lakatos, E. (2003). Fundamentos da metodologia científica (5.a ed.). São Paulo: Editora Atlas.

Maroco, J. (2003). Análise Estatística com Utilização do SPSS (2.a ed.). Lisboa: Edições Sílabo.

Maroco, J. (2010). Análise de equações estruturais. Pero Pinheiro: Report Number.

Marshall, B. \& Dewe, P. (1997). An investigation of the components of moral intensity. Journal of Business Ethics, 16(5), 521-529.

May, D. \& Pauli, K. (2002). The Role of Moral Intensity in Ethical Decision Making: A Review and Investigation of Moral Recognition, Evaluation, and Intention. Business \& Society, 41(1), 84-117.

McMahon, J. \& Harvey, R. (2007). The effect of moral intensity on ethical judgment. Journal of Business Ethics, 72(4), 335-357.

Melo, C. \& Silva, C. (2010). Finanças comportamentais: um estudo da influência da faixa etária, gênero e ocupação na aversão à perda. Revista de Contabilidade e Organizações, 4(8), 3-23.

Ministério das Finanças (2015). Estrutura Conceptual. Aviso n.․ 8254/2015.

Miranda, M. M. B. (2013). Efeitos do Processamento Sociocognitivo na Tomada de Decisão Ética. Dissertação de mestrado não publicada, Escola de Ciências Sociais e Humanas - ISCTE-IUL, Lisboa.

Moreira, J. (2009). Questionários: Teoria e Prática. Coimbra: Almedina.

Pereira, S. F. V. (2014). Ética e moral no processo de tomada de decisão: 0 caso dos alunos de Ciências Económicas e Empresariais. Dissertação de mestrado não publicada, Universidade do Minho, Braga.

Pohling, R., Bzdok, D., Eigenstetter, M., Stumpf, S. \& Strobel, A. (2015). What is Ethical Competence? The Role of Empathy, Personal Values, and the Five-Factor Model of Personality in Ethical Decision-Making. Journal of Business Ethics, 2011(March 2011). 
Rascão, J. (2012). Novas Realidades na Gestão e na Gestão da Informação. Lisboa: Edições Sílabo.

Rest, J., Bebeau, M. \& Volker, J. (1986). An Overview of the Psychology of Morality. In Rest, J. (eds.). Moral Development. (pp. 1-27). New York: Praeger Publishers.

Robin, D., Reidenbach, R. \& Forrest, P. (1996). The perceived importance of an ethical issue as an influence on the ethical decision-making of ad managers. Journal of Business Research, 35(1), 17-28.

Sadowski, C. J., \& Cogburn, H. E. (1997). Need for Cognition in the Big-Five Factor Structure. The Journal of Psychology, 131(3), 307-312.

Shafer, W. \& Simmons, R. (2011). Effects of organizational ethical culture on the ethical decisions of tax practitioners in mainland China. Accounting, Auditing \& Accountability Journal, 24(5), 647-668.

Silva, V. H. (2009). Efeitos da Responsabilização na Tomada de Decisão Ética. Dissertação de mestrado não publicada, ISCTE-IUL, Lisboa.

Simon, H. (1959). Theories of Decision-Making in Economics and Behavioral Science. The American Economic Review, 49(3), 253-283.

Simon, H. (2013). Administrative Behavior (4th ed.). London: Simon and Schuster.

Singhapakdi, A., Vitell, S. \& Kraft, K. (1996). Moral intensity and ethical decisionmaking of marketing professionals. Journal of Business Research, 36(95), 245255.

Sonenshein, S. (2007). The role of construction, intuition, and justification in responding to ethical issues at work: The sense making-intuition model. Academy of Management Review, 32(4), 1022-1040.

Sweeney, B. \& Costello, F. (2009). Moral Intensity and Ethical Decisionmaking: An Empirical Examination of Undergraduate Accounting and Business Students. Accounting Education, 18(1), 75-97.

Trevino, L. \& Brown, M. (2004). Managing to be ethical: debunking five business ethics myths. The Academy of Management Executive, 18(1), 6981.

Tversky, A. \& Kahneman, D. (1981). The Framing of Decisions and the Psychology of Choice. Science, 211(4481), 453-458.

Woiceshyn, J. (2011). A Model for Ethical Decision Making in Business: Reasoning, Intuition, and Rational Moral Principles. Journal of Business Ethics, 104(3), 311-323.

Received: 20 June 2016

Revisions required: 10 October 2016

Accepted: 02 February 2017 